\title{
Defense Responses in Grapevine Leaves Against Botrytis cinerea Induced by Application of a Pythium oligandrum Strain or Its Elicitin, Oligandrin, to Roots
}

\author{
N. Mohamed, J. Lherminier, M.-J. Farmer, J. Fromentin, N. Béno, V. Houot, M.-L. Milat, and J.-P. Blein
}

UMR 0692 INRA-Université de Bourgogne-ENESAD, Laboratoire de Phytopharmacie et Biochimie des Interactions Cellulaires, BP 86510, 21065 Dijon Cedex, France. First and second authors contributed equally to this work. Accepted for publication 22 November 2006.

\section{ABSTRACT}

Mohamed, N., Lherminier, J., Farmer, M.-J., Fromentin, J., Béno, N., Houot, V., Milat, M.-L., and Blein, J.-P. 2007. Defense responses in grapevine leaves against Botrytis cinerea induced by application of a Pythium oligandrum strain or its elicitin, oligandrin, to roots. Phytopathology 97:611-620.

Pythium oligandrum is known to display antagonistic activities against several species of pathogenic fungi. It also produces an elicitor of plant defense named oligandrin, which belongs to the elicitin family $(10-\mathrm{kDa}$ proteins synthesized by Phytophthora and Pythium species). Here, the potential of $P$. oligandrum or its purified elicitin to limit the progression of $B$. cinerea on grapevine leaf and the resulting plant-microorganism interactions are described. P. oligandrum or oligandrin were applied to roots, and changes in the ultrastructure and at the molecular level were examined. When $B$. cinerea was applied to leaves of pretreated plants, leaf invasion was limited and the protection level reached about $75 \%$. On leaf tissues surrounding $B$. cinerea inoculation, modifications of cuticle thickness, accumulation of phenolic compounds, and cell wall apposition were observed, indicating that grapevine can be considered reactive to elicitins. No macroscopic hypersensitive reaction associated with the elicitation treatment was observed. At the molecular level, the expression of three defense-related genes (LTP-1, $\beta$-1,3-glucanase, and stilbene synthase) was studied. RNAs isolated from $B$. cinerea-infected leaves of grapevine challenged or not with $P$. oligandrum or oligandrin were analyzed by real-time reverse transcription-polymerase chain reaction. In grapevine leaves, LTP-1 gene expression was enhanced in response to oligandrin, and RNA transcript levels of $\beta$-1,3-glucanase and stilbene synthase increased in response to all treatments with different magnitude. Taken together, these results open new discussion on the concept of plant reactivity to elicitins, which has until now, been mainly based on plant hypersensitive responses.

Additional keywords: plant-pathogen interactions, Vitis vinifera.
Grapevine (Vitis vinifera L.), one of the most economically important fruit species grown around the world, is susceptible to many fungal pathogens, such as Botrytis cinerea which induces gray mold disease at various developmental stages and on different plant organs (22). Until now, the disease has been controlled via fungicide sprayings. However, due to the negative impact of phytochemicals on both the environment and the quality of food products, in addition to the development of fungal resistance (31), efforts are now focused on finding alternative methods of control. Such methods involve either biological control or the use of elicitors of plant defense. Originally, biological control agents included microorganisms that display antagonistic activities against soilborne pathogens leading to plant protection (12). Later, applications of these protective strains to control aerial pathogens were proposed. In the case of $B$. cinerea, bacteria (39), yeast $(35,48)$ and fungi $(20,25)$ have been shown to display antagonism or mycoparasitism. However, their efficiency in vineyards remains to be established since, when soilborne protective microorganisms are applied by spraying, it is difficult to ensure their survival on aerial plant organs. Some have been used as biocontrol agents, among them, Trichoderma harzianum has been shown to be effective against $B$. cinerea and formulated as Trichodex (16). Recently, Le Floch et al. (30) showed that Pythium oligandrum Drechsler inoculation of tomato roots can protect the plants against $B$. cinerea. In this case, the phenomenon

Corresponding author: M.-L. Milat; E-mail address: milat@epoisses.inra.fr

doi:10.1094/PHYTO-97-5-0611

(c) 2007 The American Phytopathological Society responsible for protection cannot be a direct interaction between the antagonist and the pathogen, but rather a signal from $P$. oligandrum itself or from the plant-microorganism interaction. $P$. oligandrum is also known to secrete an elicitor of plant defense, oligandrin (41), which belongs to a family of proteinaceous elicitors, the elicitins (42). To date, the target plants used in protection studies have been mainly tobacco (Nicotiana tabacum var. Xanthi) and tomato (Lycopersicon esculentum Mill.), and protection against Phytophthora parasitica (41) and phytoplasma (32) has been shown. Chemicals or elicitors (other than elicitins) produced by microorganisms, resulting from plant-microorganism interactions such as laminarin or chitosan have been tested for their capacity to induce grapevine defense reactions against fungal pathogens $(2,3,6)$. Relevant genes associated with the defense mechanisms of grapevine include those involved in the production of stilbenic phytoalexins, mainly stilbene synthase $(1,9,27,44)$. The gene expression and activities of pathogenesisrelated (PR) proteins such as chitinases, $\beta$-1,3-glucanases $(7,10,46,47,51)$, and nonspecific lipid-transfer proteins (nsLTP) (18) also have been largely studied and related to defense responses.

In this present study, our first objective was to determine if inoculation with $P$. oligandrum, or treatment with its corresponding elicitin, oligandrin, could trigger defense reactions in grapevine and induce protection against the pathogen, $B$. cinerea. Changes in ultrastructure resulting from the plant-microorganism interactions were examined and some investigations at the molecular level were performed. The second objective was to compare these data with the previous data which concern elicitins and mainly tobacco. 


\section{MATERIALS AND METHODS}

Plant material. V. vinifera cv. Pinot noir (clone 113) grapevine shoots were provided by J.-M. Menant from BIVB (Bureau Interprofessionnel des Vins de Bourgogne), Beaune, France. Herbaceous cuttings (about $10 \mathrm{~cm}$ long) were planted in vermiculite in a growth chamber at $20^{\circ} \mathrm{C}$ (day) and $18^{\circ} \mathrm{C}$ (night) with a 16-h photoperiod (a $180 \mu \mathrm{E} \mathrm{m} \mathrm{m}^{-2} \mathrm{~s}^{-2}$ light irradiance) and a controlled hygrometry $(60 \pm 8 \%)$. Rooted cuttings were obtained and used for bioassay, when three to four expanded leaves were formed. At that time, the root system was composed of 10 to 15 roots, $10 \pm 5 \mathrm{~cm}$ long.

Fungal inoculum preparation. $P$. oligandrum, strain Py 7 , isolated from garlic by Dr. Mugnier (in the southwest of France) was provided by M. Ponchet from the IPMSV collection (IPMSV, [Interactions Plantes-Microorganismes et Santé Végétale] INRA, Antibes, France). It was maintained on malt-agar medium (1\%, $\mathrm{wt} / \mathrm{vol})$ at $25^{\circ} \mathrm{C}$ in the dark. Inoculum for plant protection assays was obtained as follows: P. oligandrum was grown in petri dishes containing V8 vegetable juice, diluted five times with water, for 4 days. To obtain larger amounts of inoculum, the method described by McQuilken et al. $(36,37)$ was used: the mycelium was transferred in Roux flasks containing $100 \mathrm{ml}$ of glucoseasparagine medium to which cholesterol was added $(30 \mathrm{mg} / \mathrm{ml}$ final concentration). After 21 days of culture at $25^{\circ} \mathrm{C}$ in the dark, mycelium was removed by filtration on a Whatman No. 1 filter paper, mycelial mats were rinsed three times with sterile water and ground with water in a Potter tube. For root inoculation, the density of the fungal inoculum was adjusted to $25 \times 10^{4}$ oospores in $25 \mathrm{ml}$ (which corresponds to about $60 \mathrm{mg}$ fresh weight of mycelium).

B. cinerea (strain Bc-3) (provided by B. Paul, IUVV [Institut Universitaire de la Vigne et du Vin]-Université de Bourgogne, Dijon, France) was maintained on malt-agar medium $(1 \%, \mathrm{wt} / \mathrm{vol})$ and subcultured every 3 weeks on the same medium. For grapevine inoculation, $B$. cinerea was grown on potato dextrose broth (PDB) (Sigma, St. Louis, MI) for 8 days. Both cultures were performed at $25^{\circ} \mathrm{C}$ in the dark.

Oligandrin. Oligandrin (from $P$. oligandrum strain Py 7), provided by M. Ponchet (IPMSV, INRA, Antibes, France), was purified as previously described by Lascombe et al. (28). It is the same protein as that previously purified from another strain of P. oligandrum (Po 1010) isolated from pea in Denmark and used in previous works $(4,41)$ (their cDNAs are identical).

Grapevine protection bioassay. Three independent assays were performed with nine plants for each condition. For each assay, three groups of 18 plants were treated at the root level with either P. oligandrum inoculum, oligandrin, or water as the control. Each group was then divided into two series, with or without $B$. cinerea leaf inoculation (described below). The plants were maintained in a growth chamber (described previously) during the experiment except, after $B$. cinerea inoculation, the relative humidity was raised to $100 \%$.

Grapevine root inoculation with $P$. oligandrum. $P$. oligandrum inoculation was performed by immersing the roots of 18 plants for $1 \mathrm{~h}$ in $25 \mathrm{ml}$ (for each plant) of an oospore and mycelium suspension obtained as described above. Plants were then transferred into pots containing soil and the remaining P. oligandrum inoculum was poured onto the soil surface. The 18 control plants were treated the same way except that the inoculum was replaced by water.

Grapevine root treatment with oligandrin. For another group of 18 plants, the roots were rolled and dipped in tubes containing $5 \mu \mathrm{g}$ of oligandrin dissolved in water $(1 \mathrm{ml})$. Once the solution had been absorbed ( 3 to $6 \mathrm{~h}$ ), the plants were transferred into pots containing soil.

Grapevine leaf inoculation with $B$. cinerea. Plants were infected with $B$. cinerea the same day, i.e., 7 days after $P$. oligan- drum inoculation or 2 days after oligandrin treatment of the grapevine roots. $B$. cinerea mycelium disks of actively growing hyphae $(0.5 \mathrm{~cm}$ in diameter) removed from 8-day-old cultures on PDB were placed on the upper surface of three leaves per grapevine plant (one disk per leaf). This constitutes 27 replicates per assay. For each experimental series, inoculation was performed on leaves that were carefully chosen (similar size and position of insertion). After 1, 2, 3, 5, and 7 days, the development of $B$. cinerea was estimated by measuring the areas of the lesions around the mycelial disks. $B$. cinerea leaf invasion is expressed as the percentage of damaged tissue of the total leaf areas and protection against $B$. cinerea as the percentage of the difference between the necrosed areas of the damaged tissues of nonelicited plants and that of the elicited ones, divided by that of nonelicited ones. The statistical analyses of data include an analysis of variance with a significance level of $P<0.05$.

Analyses of grapevine-microorganism interaction by microscopy. For each experimental series, samples of leaf and root tissues were removed from three grapevine plants, 7 days after $B$. cinerea infection, i.e., 14 days after $P$. oligandrum inoculation and the corresponding control and 9 days after oligandrin treatment. From plants challenged with $B$. cinerea, samples of leaf tissues were removed 1 to $2 \mathrm{~cm}$ from the necrotic zone of infection. For noninfected leaves, samples were removed from corresponding areas. Morphological modifications of both plant tissues and microorganisms were analyzed.

From leaf tissues of each of the three series inoculated with $B$. cinerea, five embedded blocks were sectioned and for each block, three levels of sectioning were selected with the light microscope (for which at least two B. cinerea hyphae were visible on the leaf surface) before being examined with the transmission electron microscope. The same sampling strategy was used for $P$. oligandrum or oligandrin pretreated plants noninfected with $B$. cinerea although the three levels of sectioning in each block were randomly performed.

Sampling of tertiary lateral roots was randomly done on control plants and $P$. oligandrum or oligandrin pretreated plants. Three different embedded blocks were sectioned at three levels: one in root tip and two in root regions where vascular tissues were differentiated.

Assessment of grapevine root colonization by $\boldsymbol{P}$. oligandrum. Root colonization by $P$. oligandrum was assessed using the trypan-blue staining method proposed by Phillips and Hayman (40). Root systems were removed, heated at $90^{\circ} \mathrm{C}$ for $30 \mathrm{~min}$ in $10 \% \mathrm{KOH}$ (to clear the tissues), rinsed in tap water, and stained in $0.05 \%$ lactophenol trypan-blue solution for $30 \mathrm{~min}$ at $90^{\circ} \mathrm{C}$. The roots were then examined by bright field microscopy (described below).

Analyses of grapevine-microorganism interaction by light and transmission electron microscopy. Plant tissues were excised in $0.1 \mathrm{M}$ sodium phosphate buffer ( $\mathrm{pH}$ 7.2) containing 3\% (vol/vol) glutaraldehyde and $2 \%$ (wt/vol) paraformaldehyde. They were then immersed in the fixative solution under vacuum for $4 \mathrm{~h}$ at $4^{\circ} \mathrm{C}$, post-fixed with $1 \%(\mathrm{wt} / \mathrm{vol})$ osmium tetroxide in the same buffer for $1 \mathrm{~h}$ at $4^{\circ} \mathrm{C}$, and embedded in Epon (Spi-Chem Neyco, Paris, France) according to the usual procedure (34). Thick and ultrathin sections were cut with a Reichert Ultracut E microtome (Leica, Rueil-Malmaison, France). Thick sections $(0.5 \mu \mathrm{m})$ were mounted on glass slides and stained with $0.1 \%(\mathrm{wt} / \mathrm{vol})$ toluidine blue, $\mathrm{pH}$ 11, prior to examination by bright field microscopy with a DMRB microscope (Leica, Rueil-Malmaison, France). Black and white images were recorded with a Hamamatsu Orca 100 camera coupled with image analysis Visilog software (Noesis, Les Ulis, France). Ultrathin sections collected on grids were counterstained with 3\% (wt/vol) uranyl acetate in ethanol and lead citrate for conventional transmission electron microscopy. Sections were examined with a Hitachi 7500 (Hitachi Scientific Instruments Co., Tokyo, Japan) transmission electron microscope operating at $80 \mathrm{kV}$ 
and equipped with an AMT camera driven by AMT software (AMT Corp., Danvers, MA).

Cuticle structure and thickness were examined on transversal thin leaf sections. For each series, 15 micrographs, taken from three sections made on each of three blocks, were recorded and analyzed. In the case of $B$. cinerea infection, measurements of cuticle thickness were performed where $B$. cinerea hyphae were visible at the leaf surface. For all plants noninfected with $B$. cinerea, measurements were randomly done on examined sections.

Analyses of root tissues inoculated with $P$. oligandrum by scanning electron microscopy (SEM). Fully hydrated root samples were placed and maintained at $-10^{\circ} \mathrm{C}$ in a variable pressure chamber of a Hitachi S-3000N SEM (Hitachi Scientific Instruments Co., Tokyo, Japan) equipped with an Environmental Secondary Electron Detector and operating at $15 \mathrm{kV}$ with a pressure chamber of $110 \mathrm{~Pa}$.

Reverse transcription-polymerase chain reaction quantification of defense-associated gene transcripts in grapevine leaf tissues: RNA extraction. Total RNA was isolated from grapevine leaves ( $V$. vinifera $\mathrm{cv}$. Pinot noir) using the method proposed by Chang et al. (11) and further purified using the Rneasy MinElute Cleanup kit (Qiagen GmbH Hilden, Germany).

Real-time reverse transcription-polymerase chain reaction analysis. RNAs $(1 \mu \mathrm{g})$ from the different leaf samples were incubated in the presence of 1 unit of RQ1 RNase free DNase (Promega, Madison, WI) according to the manufacturer's instructions. Non-reverse-transcribed RNA samples were checked for the absence of contaminating genomic DNA by polymerase chain reaction (PCR) using primers for constitutively expressed actin (7). Samples were then reverse-transcribed using iScript cDNA Synthesis Kit (Bio-Rad, Hercules, CA), and diluted to a final volume of $400 \mu \mathrm{l}$.

Reverse transcription (RT)-PCR analyses were carried out in duplicate in a Bio-Rad Icycler (Bio-Rad) in a final volume of $25 \mu \mathrm{l}$ containing $5 \mu \mathrm{l}$ of diluted cDNA, $200 \mathrm{nM}$ of each primer, and $12.5 \mu \mathrm{l}$ of iQ SYBR Green Supermix (Bio-Rad) for 50 cycles of $10 \mathrm{~s}$ at $95^{\circ} \mathrm{C}, 20 \mathrm{~s}$ at $59^{\circ} \mathrm{C}$, and $30 \mathrm{~s}$ at $72^{\circ} \mathrm{C}$. Two no-template (water) control wells and one non-reverse-transcribed sample were included as negative controls for each primer pair. Standard curves were generated for each primer pair by performing realtime PCR on serial dilutions (in duplicate) of a specific purified PCR product. Real-time PCR efficiencies were derived from standard curves constructed on the target gene, and were checked to be between 90 and $110 \%$.

To establish the presence of a single PCR product and the absence of primer-dimer, melting analysis was done immediately after PCR by increasing the set point temperature, in $20 \mathrm{~s}$, from 59 to $96^{\circ} \mathrm{C}$ by $0.4^{\circ} \mathrm{C}$ steps.

Primers used for actin, $\beta$-1,3-glucanase, and stilbene synthase gene expression are as published by Bonomelli et al. (9). Primers for grapevine LTP1 (VitLTP1-F1: GATGGTGATATGCATGGTGGTGG, VitLTP1-R1: CTRCAGCACCCAGSTGGCACTG) were designed on the basis of accessions AF465408.1, AF467945.1, AF467946.1 from GenBank database.

Relative gene expression was calculated using the $\Delta \Delta \mathrm{C}_{\mathrm{T}}$ method described by Livak and Schmittgen (33) and grapevine actin as a constitutive gene (7).

\section{RESULTS}

Grapevine protection against $B$. cinerea associated with $\boldsymbol{P}$. oligandrum or oligandrin treatment. The development of B. cinerea on $V$. vinifera $\mathrm{cv}$. Pinot noir was monitored for 7 days following its application on leaves of rooted cuttings. Grapevine plants subjected to either $P$. oligandrum inoculation or oligandrin pretreatment exhibited reduced leaf lesions compared with nonpretreated plants (Fig. 1). Under both conditions, the decrease of symptom intensities was very noticeable 3 days after inoculation with the foliar pathogen: the lesions caused by $B$. cinerea infection represent $16.5,13$, and $38.5 \%$ of the leaf areas for the plants treated with $P$. oligandrum, oligandrin, and the non-pretreated plants, respectively (Fig. 1). Thus, the degree of protection obtained with $P$. oligandrum or oligandrin could be estimated at 57 and $66 \%$ (compared with the necroses measured for plants infected by $B$. cinerea without pretreatment), respectively. Five and seven days after $B$. cinerea inoculation, the phenomenon was even more obvious. For the final measurements, in the nonpretreated plants, the spread of $B$. cinerea infection resulted in the rotting of infected leaves that finally fell from the stem, whereas in the other two cases, pathogen progression was slowed and protection could be estimated at $64 \%$ for P. oligandrum pretreatment and $73 \%$ for oligandrin pretreatment. Thus, protection was slightly more efficient with oligandrin pretreatment than with $P$. oligandrum preinoculation throughout the experiment (Fig. 1B). Neither oligandrin nor $P$. oligandrum induced macroscopic foliar necrotic features typically associated with hypersensitive reaction.

Colonization of grapevine roots by $P$. oligandrum and studies of the morphology of root tissues and hyphae. At the end of these experiments, i.e., 2 weeks after $P$. oligandrum inoculation, root branches were sampled and examined: roots (inoculated or not) displayed the same architecture and no necrotic lesions were visible on the $P$. oligandrum-inoculated roots. Oogonia (Fig. 2A) and germinated zoospores (Fig. 2B), which characterize the sexual and asexual life cycles of oomycetes, were regularly dispersed on the root surface of lateral tertiary roots in the mature region. Most of the hyphae emerging from these zoospores had established close contact via appressorium structures with the root surface, and appeared to penetrate tissues at a short distance from the germinated spore (Fig. 2B). In addition, we noticed that only a few hyphae had grown over the root surface, showing light network organization. The fungus was never detected in the apical region of the root. SEM revealed that the hyphae were able to penetrate within the root through intercellular spaces of the epidermis (Fig. 2C). Hyphae were mainly restricted to intercellular spaces between the epidermis and the first outer cortex cells (Fig. 2D). Attempts to penetrate host cell wall by $P$. oligandrum occurred, as seen in Figure 2E, but hyphae failed to penetrate or to disrupt the host cell wall. In

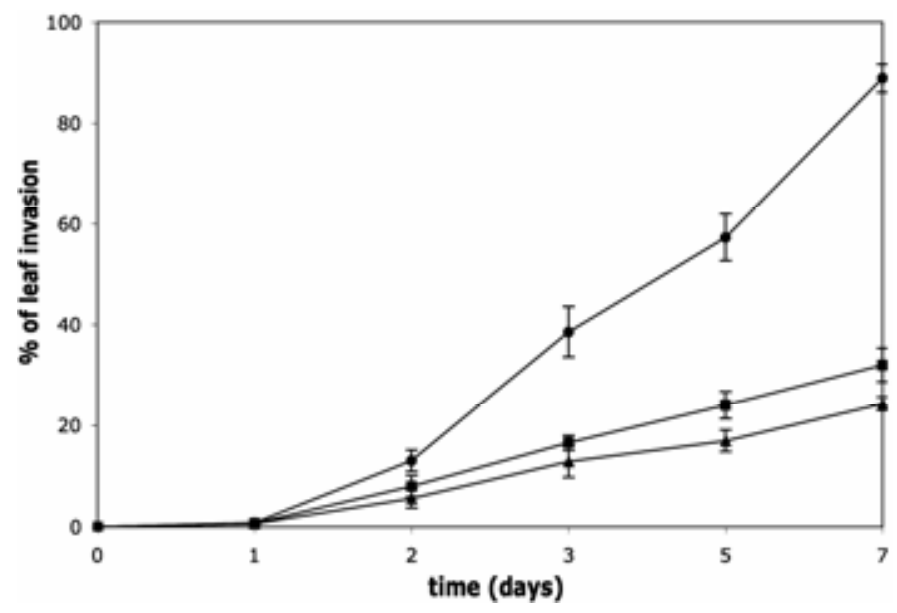

Fig. 1. Time-course development of gray mold (Botrytis cinerea) on Pinot noir rooted cuttings preinoculated with Pythium oligandrum or pretreated with oligandrin, both at the root level, 7 and 2 days, respectively, before $B$. cinerea inoculation, for $B$. cinerea without elicitation $(\bullet)$, with a $P$. oligandrum preinoculation $(\boldsymbol{\square})$, and with an oligandrin pretreatment $(\boldsymbol{\Delta})$. The disease assessment was determined by measuring the average areas \pm standard error of lesions formed 1, 2, 3, 5, and 7 days after inoculation ( 27 replicates) expressed as the percentage of the total leaf area. The experiment was repeated three times. 
this grapevine- $P$. oligandrum interaction, host cell walls in contact with the fungus do not exhibit alterations commonly observed when enzymatic degradation occur in planta. The hyphae were highly vacuolated and exhibited altered cytoplasmic content. Cortical host cells also exhibited cytoplasmic content disorganization (Fig. 2D and E). However, no major morphological modifications were observed in $P$. oligandrum-inoculated plants either in leaf or in root tissues compared with the control plants.

Histological and ultrastructural features of oligandrintreated grapevine root and leaf tissues. Compared with the roots of control plants (Fig. 3A), transverse sections of oligandrin-treated root tissues mostly revealed histological modifications in epidermal and endodermal cells (Fig. 3B). Toluidine-blue stained deposits, which also appeared as electron-dense bodies in transmission electron microscopy (Fig. 3C), had accumulated in the vacuoles. These deposits were previously commonly identified as phenolic compounds.
Observations of thin sections of leaves of oligandrin-treated plants revealed cytological changes suggesting plant defense responses. Palisade and spongy parenchyma cells exhibited electron-opaque structures resembling phenolic inclusions that had accumulated and bordered the tonoplast (Fig. 3D). These compounds also accumulated in vacuoles of phloem parenchyma cells (Fig. 3E). Moreover, occlusions of the lumen of mature sieve tubes of phloem bundles by phloem proteins (P proteins) were regularly observed (Fig. 3E).

Development of $B$. cinerea infection in symptomless leaf tissues of nonelicited grapevine plants. Some initial events of the $B$. cinerea colonization pattern were observed in nonnecrotic areas of infected grapevine leaves. Fungal cells from 7 to $10 \mu \mathrm{m}$ in diameter, with dense cytoplasm and clearly visible organelles (Fig. 4A) established contact with the leaf surface. Infecting hyphae were also seen inside epidermal cells. The cytoplasm of host epidermal cells was also altered. Most of the hyphae seen on the leaf surface seemed to penetrate leaf tissues through natural

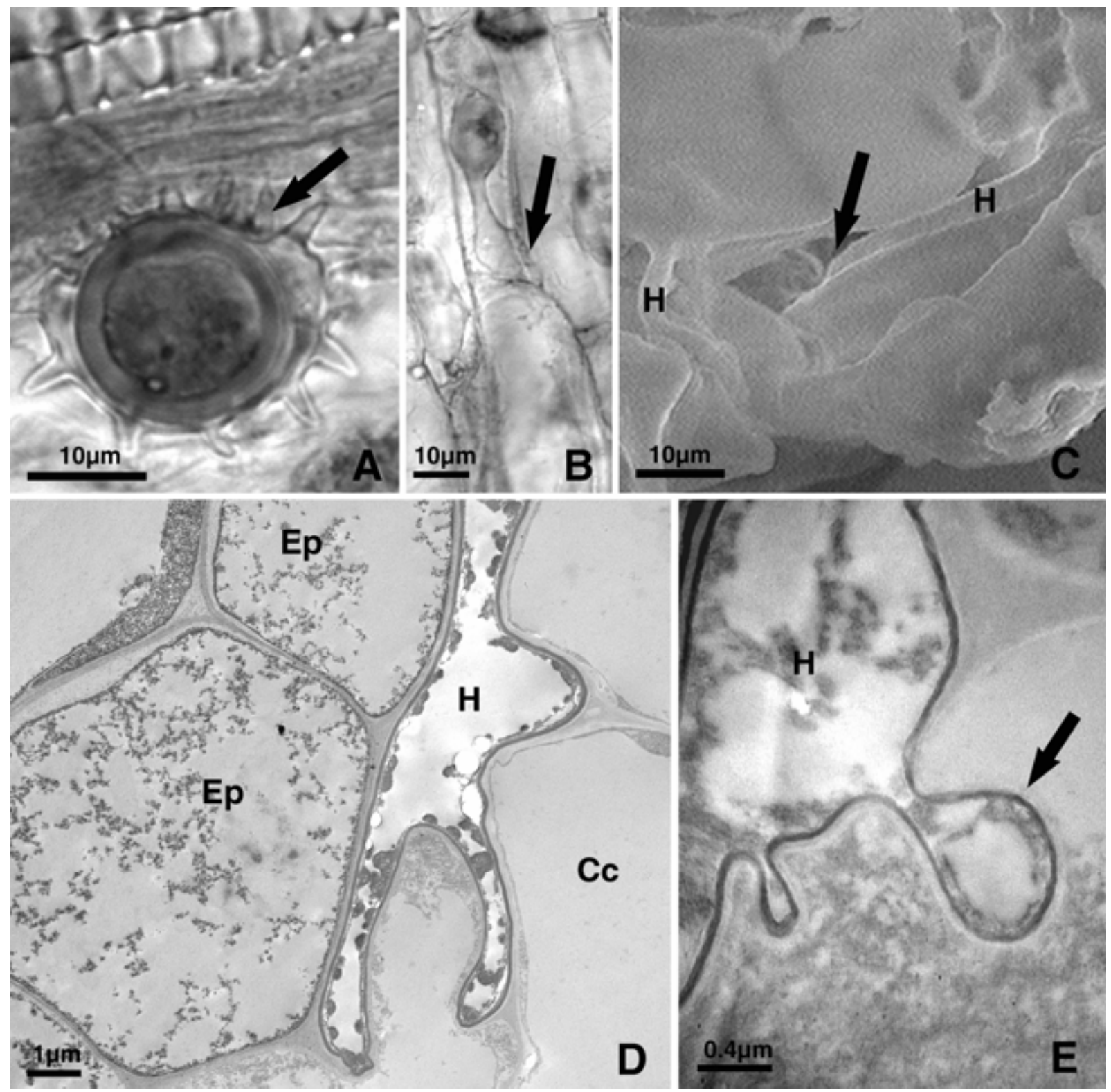

Fig. 2. Pythium oligandrum colonization of grapevine (Pinot noir) roots 14 days after inoculation. A and B, Light microscope observations of grapevine roots stained with lactophenol-trypan blue. A, Oogonium (arrow) and $\mathbf{B}$, germinated zoospore with germ tube forming appressorium structures (arrow) visualized on the root surface. C, Scanning electron microscopy: presence of hyphae $(\mathrm{H})$ on the grapevine root surface and evidence of penetration through intercellular spaces (arrow). D and E, Transmission electron micrographs of transverse section of a tertiary root. D, Hypha (H) in intercellular space between epidermis (Ep) and the first cortical cell $(\mathrm{Cc})$ layer of the roots exhibiting high vacuolation and altered cytoplasmic content. E, Failure of host cell penetration attempts by $P$. oligandrum hypha $(\mathrm{H})$ and plant cell wall folding without disruption (arrow). 
openings such as stomata (Fig. 4B). These results were confirmed by direct light microscopy observations of fresh leaves that showed that $B$. cinerea penetration occurred mostly by stomata and involved hyphae or protoappressoria (data not shown). In the leaf area studied here, $B$. cinerea did not grow in other tissues. Fronting the pathogen hyphae, impregnation of the epidermal cell walls with electron-dense material and indentation of the cuticle were detected (Fig. 4C). The cuticle appeared less osmiophilic, as shown by the reduced electron density (Fig. 4D), than the wax cover of unchallenged leaves (Fig. 4E). Moreover, a significant reduction in the thickness of the cuticle of $B$. cinerea-infected leaves compared with the cuticle thickness of noninfected plants was noted (Table 1).

B. cinerea interaction with $P$. oligandrum preinoculated grapevine plants. Preinoculation of grapevine roots with $P$. oligandrum resulted in a reduction in leaf infection by the pathogen, $B$. cinerea. In the nonnecrotic leaf area, only a few pathogen hyphae were detected. About $50 \%$ of these hyphae exhibited marked changes including high vacuolation, lipid accumulation, and disorganization of the cytoplasm, in which mitochondria were no longer visible (Fig. 5A). Wall appositions were visualized at potential penetration sites (Fig. 5A and B). These appositions displayed a matrix impregnated with electron-dense material delimited by a layer of translucent material, probably consisting of callose. Some hyphae appeared altered or as empty shells (Fig. 5C). Electron-dense deposits, which could be phenolic compounds, occurred in the vacuoles of palisade cells (Fig. 5D). Cuticle fronting hyphae was jagged (Fig. 5E), but its thickness was similar to that of the control plants (Fig. 4E; Table 1), or that of $P$. oligandrum-inoculated plants unchallenged with $B$. cinerea (Fig. 5F; Table 1). However, compared with B. cinerea infection alone, a significant increase could be seen $(0.25 \pm 0.03 \mu \mathrm{m}$ instead of $0.16 \pm 0.02 \mu \mathrm{m})$.

B. cinerea interaction with oligandrin pretreated grapevine plants. In oligandrin pretreated grapevine plants, electron microscope studies of the colonization pattern of $B$. cinerea revealed that $80 \%$ of the fungal cells attached to the leaf surface were altered (Fig. 6A). Moreover, part of mycelium was completely devoid of cytoplasm content (Fig. 6B). Electron-dense cuticle layers, stained with osmium tetroxide, specific of lipid components (Fig. 6C), were always significantly thicker than that of the pretreated plants unchallenged with $B$. cinerea and the phenomenon was more pronounced than that observed with P. oligandrum preinoculation (Fig. 6D; Table 1). Some epidermis cell walls were impregnated with compounds possibly of phenolic nature (Fig. 6E and F). Strong plant defense responses also occurred locally in epidermis and parenchyma cells, such as reinforcement of cell walls with electron-dense material and translucent deposits along the primary cell wall (Fig. 6G). There was some evidence of plant cell death in the vicinity of dead hyphae (Fig. 6F). Surprisingly, electron-dense material was seen to fill the xylem vessel lumen, and reinforcement of the primary cell walls of vascular parenchyma cells with translucent layer was also visible (Fig. $6 \mathrm{H}$ ).

RT-PCR quantification of defense-associated gene transcripts in grapevine leaf tissues. The expression of three defense-related genes, LTP-1, $\beta$-1,3-glucanase, and stilbene synthase, was analyzed in grapevine leaves by real-time RT-PCR in response to treatment by oligandrin or P. oligandrum and/or to infection with $B$. cinerea. The grapevine actin gene was selected as an internal control to normalize the different samples for differences in amounts of plant RNA. Gene expression was considered enhanced when induction was greater than five times that of the untreated control leaves. This technique gave reproducible results that were confirmed by northern blot analysis (data not shown). In control leaves, the transcript levels were low except in the case of stilbene synthase. This slight induction could be a result of slight stress related to the experimental conditions.
Our experiments allowed us to compare each treatment with the control and each "double" treatment with its corresponding "single" treatment.

Transcript accumulation levels of LTP-1 in leaves at 36 or $72 \mathrm{~h}$ following infection with $B$. cinerea, in plants either preinoculated or not with $P$. oligandrum and/or infected with $B$. cinerea were similar to the control, indicating that LTP-1 expression was not enhanced in response to elicitation by $P$. oligandrum and/or inoculation with $B$. cinerea (Fig. 7A). In contrast, expression of LTP-1 increased in response to oligandrin compared with the control, with greater induction observed at $36 \mathrm{~h}$. A similar level of induction of LTP-1 expression was observed when elicitation by oligandrin was associated with $B$. cinerea infection, indicating that oligandrin was responsible for enhancing LTP-1 expression.

Compared with the control, induction of $\beta$-1,3-glucanase was observed in plants treated with oligandrin, and when oligandrin treatment was followed by inoculation with $B$. cinerea. The slight gene induction observed in plants treated with $P$. oligandrum increased following inoculation with $B$. cinerea. High levels of transcripts were found from nonelicited plants $72 \mathrm{~h}$ following inoculation with $B$. cinerea (Fig. 7B). Induction was less important when inoculation of $B$. cinerea followed treatment with $P$. oligandrum or oligandrin than with $B$. cinerea alone. In all treatments involving $B$. cinerea, transcript accumulation levels observed after $72 \mathrm{~h}$ were greater than those observed after $36 \mathrm{~h}$.

Stilbene synthase transcript levels in grapevine leaves increased in response to treatment with $P$. oligandrum, oligandrin, or B. cinerea at 36 and $72 \mathrm{~h}$ (Fig. 7C). When B. cinerea inoculation was associated with either $P$. oligandrum or oligandrin, induction levels were less important than for $B$. cinerea alone.

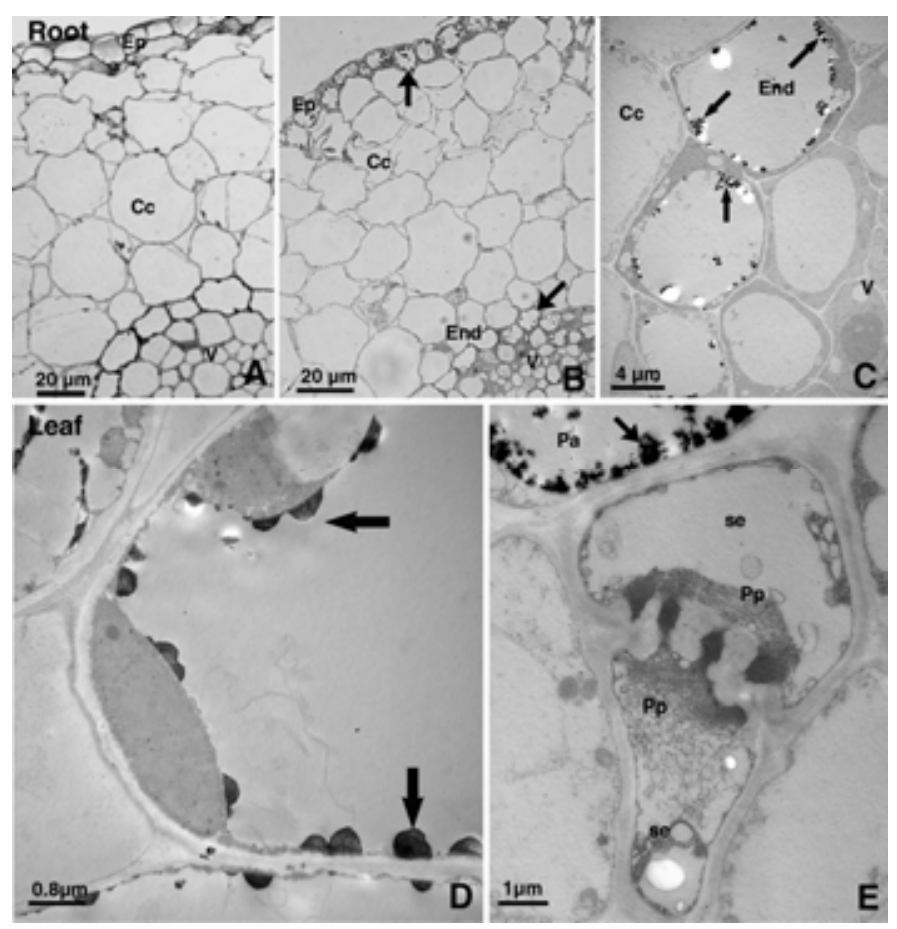

Fig. 3. Histological and cytological modifications induced by oligandrin ( 9 days after treatment) on grapevine plants in $\mathbf{A}$ to $\mathbf{C}$, root and $\mathbf{D}$ and $\mathbf{E}$, leaf tissues. A and B, Light micrograph of transverse section of grapevine root tissues stained with toluidine blue. A, control. B, Section of oligandrin-treated roots showing slight accumulation of densely stained droplets (arrows) in vacuoles of epidermis (Ep) and endodermis (End). Cc, cortical cells; V, vascular cylinder. C, Transmission electron micrograph observations of endodermal cells (End) with accumulation of material, likely phenolic compounds, in vacuoles (arrows). D and E, Thin leaf sections of oligandrintreated grapevine plants. D, Similar material regularly dispersed along the tonoplast of palisade cells (arrow), E, also visualized in parenchyma cells of phloem bundles (Pa) (arrow). Occlusion of pore sites of sieve plate with phloem proteins $(\mathrm{Pp})$ in the lumen of sieve elements (se). 


\section{DISCUSSION}

The results presented in this paper describe the ability of either P. oligandrum or oligandrin to induce grapevine defense reactions against $B$. cinerea infection. The cytological investigations gave some information on the mechanisms by which protection against $B$. cinerea infection is conferred by $P$. oligandrum or oligandrin.

In symptomless leaf tissues of non-pretreated plants, the penetration and postpenetration processes of grapevine leaves by B. cinerea occurred as already described for other plants $(13,17,23)$.

Very few studies have reported the ultrastructure features of elicitin-treated plant tissues. Benhamou et al. (4) briefly mentioned that exogenous applications of oligandrin on a tomato leaf petiole did not yield appreciable effects on the induction of plant defense reactions in root tissues. In addition, Lherminier et al. (32) previously reported that oligandrin, when applied onto the decapitated apex of stems or leaf petioles of tobacco, elicited in both, plant defense responses such as impregnation of cell walls with phenolic compounds, formation of calcium pectate gels in intercellular spaces, and accumulation of phloem proteins in phloem bundles (32). In direct line with these earlier results, in this work, some structural modifications were observed in grapevine leaves and roots after treatment of the roots with oligandrin: deposits, deemed to be phenolic compounds, appeared in the vacuoles of root endodermis cells and leaf parenchyma cells, and phloem proteins were observed in the lumen of leaf sieve tubes. Altogether, these results suggest that oligandrin elicits, in planta, typical defense responses that seem to be common to different plant species.
$P$. oligandrum and oligandrin pretreated plants appear to display resistance to $B$. cinerea infection by reinforcing protective barriers at the first steps of the infection process. They induce both cell wall appositions (papillae) and impregnation or coating of cell walls with electron-dense compounds, that are most probably phenolic compounds, which form efficient barriers in both epidermal and first parenchyma cells at potential penetration sites of the pathogen. These responses restrict progression and further penetration of $B$. cinerea into plant leaf tissues as previously reported $(15,38)$. However, in oligandrin pretreated plants, these host reactions could lead to host cell death close to $B$. cinerea penetration sites. The cuticle also appeared to be an important barrier to $B$. cinerea penetration as already reported $(15,19,45)$. In $P$. oligandrum-inoculated plants, the cuticle thickness was not significantly increased compared with that of the

TABLE 1. Cuticle thickness of noninfected versus infected grapevine leaves

\begin{tabular}{lcc}
\hline \multirow{2}{*}{$\begin{array}{l}\text { Grapevine plant root } \\
\text { system with }\end{array}$} & \multicolumn{2}{c}{ Cuticle thickness $^{\mathrm{a}} \pm \mathrm{SD}(\mu \mathrm{m})$} \\
\cline { 2 - 3 } & Noninfected leaves & $\begin{array}{c}\text { Botrytis cinerea- } \\
\text { infected leaves }\end{array}$ \\
\hline $\begin{array}{l}\text { Water pretreatment } \\
\begin{array}{l}\text { Pythium oligandrum } \\
\text { preinoculation }\end{array}\end{array}$ & $0.21 \pm 0.02(100 \%)$ & $0.16 \pm 0.02(76 \%)$ \\
Oligandrin pretreatment & $0.23 \pm 0.03(110 \%)$ & $0.25 \pm 0.03(119 \%)$ \\
\hline
\end{tabular}

${ }^{a}$ For grapevine leaves challenged with $B$. cinerea, measurements were performed where hyphae were detected on transverse sections of leaves, at a microscope magnification of $\times 40,000$. Expression of the changes in percent compared with the water treatment is indicated in parentheses.
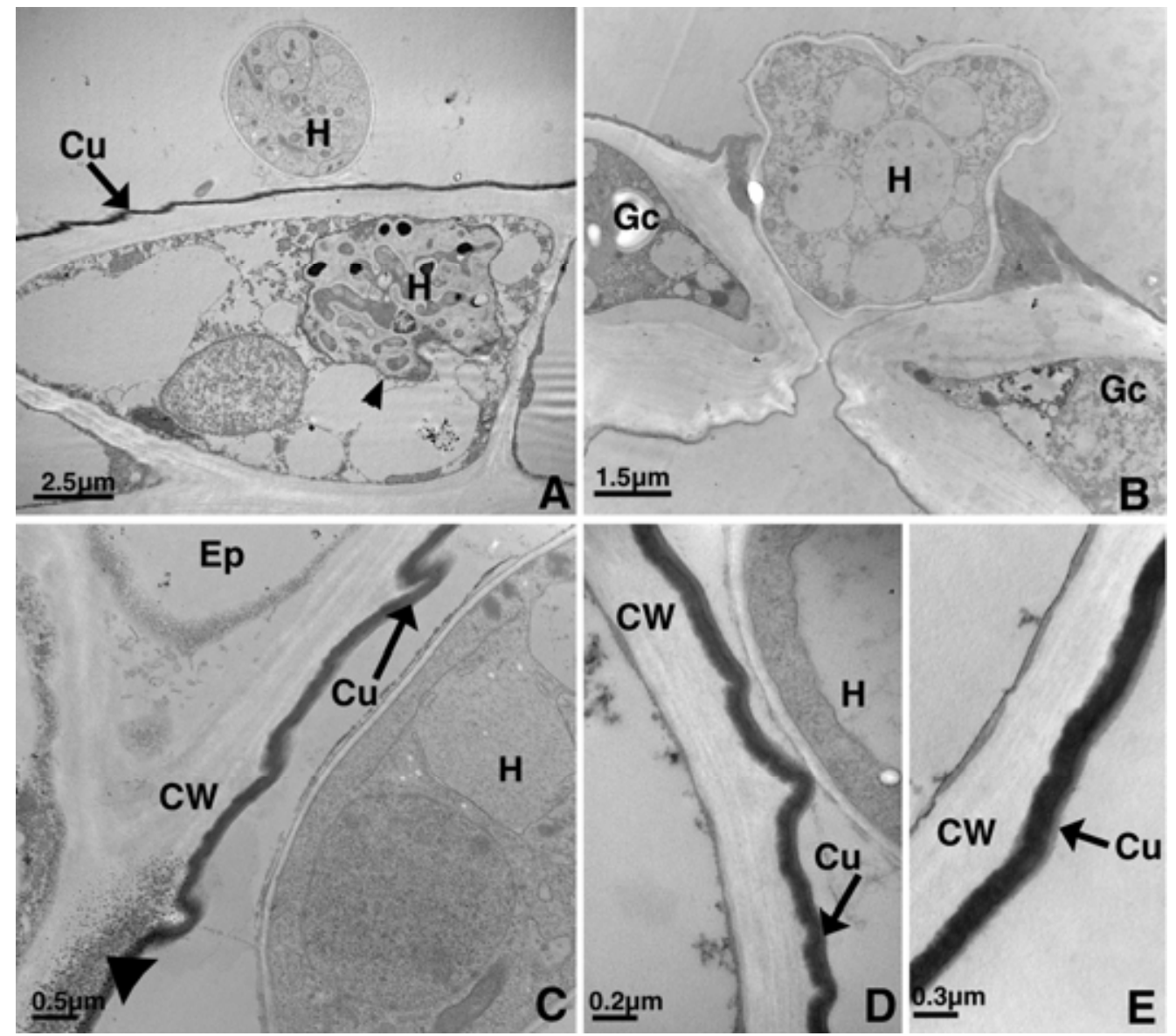

Fig. 4. Transmission electron micrographs of colonization pattern of Botrytis cinerea in symptomless area of an inoculated leaf (non-pre-treated plant). A, Jagged cuticle $(\mathrm{Cu})$ fronting a hypha $(\mathrm{H})($ arrow). Intracellular colonization of epidermal cell with branched hyphae $(\mathrm{H})$ surrounded by a membrane (arrowhead). B, Hypha $(\mathrm{H})$ penetration through stomata. Gc, guard cell. C, Slight impregnation of the primary cell wall $(\mathrm{CW})$ with electron-dense material corresponding to localized plant defense reaction (arrowhead). D, Cuticle thickness is significantly reduced $(0.16 \pm 0.02 \mu \mathrm{m})$ compared with $\mathbf{E}$, cuticle thickness of noninoculated control grapevine leaf $(0.21 \pm 0.02 \mu \mathrm{m})$. 
control. In contrast, in the presence of the pathogen hyphae, the preinoculation induced an increase in cuticle thickness compared with $B$. cinerea alone, which counteracted the degradation probably due to $B$. cinerea cutinases. In oligandrin-treated plants, cuticle was slightly thicker than that of the controls, and the increase following $B$. cinerea infection was more pronounced that with $P$. oligandrum preinoculation. Ultrastructural changes that involve the internal layering of the cuticle material occurred, suggesting an increase in fatty acid content of the cuticle membrane. Such structural modifications have already been reported in other plant-microbe interactions $(26,53)$. The hypothesis that, among the responses associated with defense against $B$. cinerea infection of oligandrin-treated and to a lesser extent, $P$. oligandrum-inoculated grapevine plants, LTP genes could be induced was confirmed by real-time RT-PCR experiments, where the elicitin oligandrin is shown to be efficient in inducing expression of transcript levels of defense-related genes, LTP-1, $\beta-1,3-$ glucanase, and stilbene synthase. LTPs in grapevine cell suspensions have been shown to be induced by defense-related signals such as ergosterol, or by a proteinaceous elicitor secreted by B. cinerea (18). During plant-pathogen interactions, nsLTPs might transport lipids (cutin monomers) to favor the synthesis of cutin at the outer surface of the epidermal cells $(21,24,50)$. This contributes to enhance the physical properties of epidermal cell walls. Moreover, these nsLTP-cutin monomer complexes are known to trigger plant defense mechanisms leading to the death of hyphae (8). Neither $P$. oligandrum nor B. cinerea alone or together induced an LTP response in grapevine. This may reflect a dose effect. $P$. oligandrum, oligandrin, and B. cinerea triggered increases in $\beta$-1,3-glucanase and stilbene synthase transcript levels. Interestingly, in both cases, both $\beta$-1,3-glucanase and stilbene synthase appeared to be less induced when $B$. cinerea was associated with either oligandrin or P. oligandrum. This could be due to a different kinetics of accumulation, with a maximum reached earlier when the elicitation is applied. $\beta-1,3-$ Glucanase is an important PR protein involved in protection against fungal attack. Stilbene synthase is a key enzyme in the production of phytoalexins, and is a well-characterized defense reaction in grapevine (49). Bézier et al. (7) reported stilbene synthase gene expression in grapevine leaves infected with $B$. cinerea. An accumulation of stilbene synthase transcripts also was detected during grapevine leaf and Pseudomonas syringae incompatible interactions with a maximum about $72 \mathrm{~h}$ after inoculation (46).

The ability of $P$. oligandrum to colonize grapevine roots is very poor and its ingress is restricted to the epidermis cell layer. No host defense reactions were seen either in roots or in aerial organs of these $P$. oligandrum-colonized grapevine plants. This restricted colonization was associated with minor damage to the root cells adjacent to Pythium hyphae, whereas structural alterations of invading $P$. oligandrum hyphae have been seen. This $P$. oligandrum root colonization pattern has previously been mentioned on rice (14) and cucumber roots (52). In contrast, it has been reported that $P$. oligandrum extensively colonizes tomato roots $(5,29,43)$, and that this phenomenon is associated with host defense reactions such as the formation of papillae-like structures at sites of hypha penetration (5). Therefore, the interaction between $P$. oligandrum and plants seems to display some host specificities. Although $P$. oligandrum is largely distributed in vineyard soils, our experiments suggest that grapevine is a nonhost plant for this Pythium species. Nevertheless, despite its poor colonization ability, $P$. oligandrum can protect grapevine plants from $B$. cinerea attack. P. oligandrum is known to secrete oligandrin in vitro and it is probably able to secrete this protein in planta, but in an amount inferior to the one we applied. This could explain the slightly higher degree of protection with oligandrin treatment compared with $P$. oligandrum inoculation.

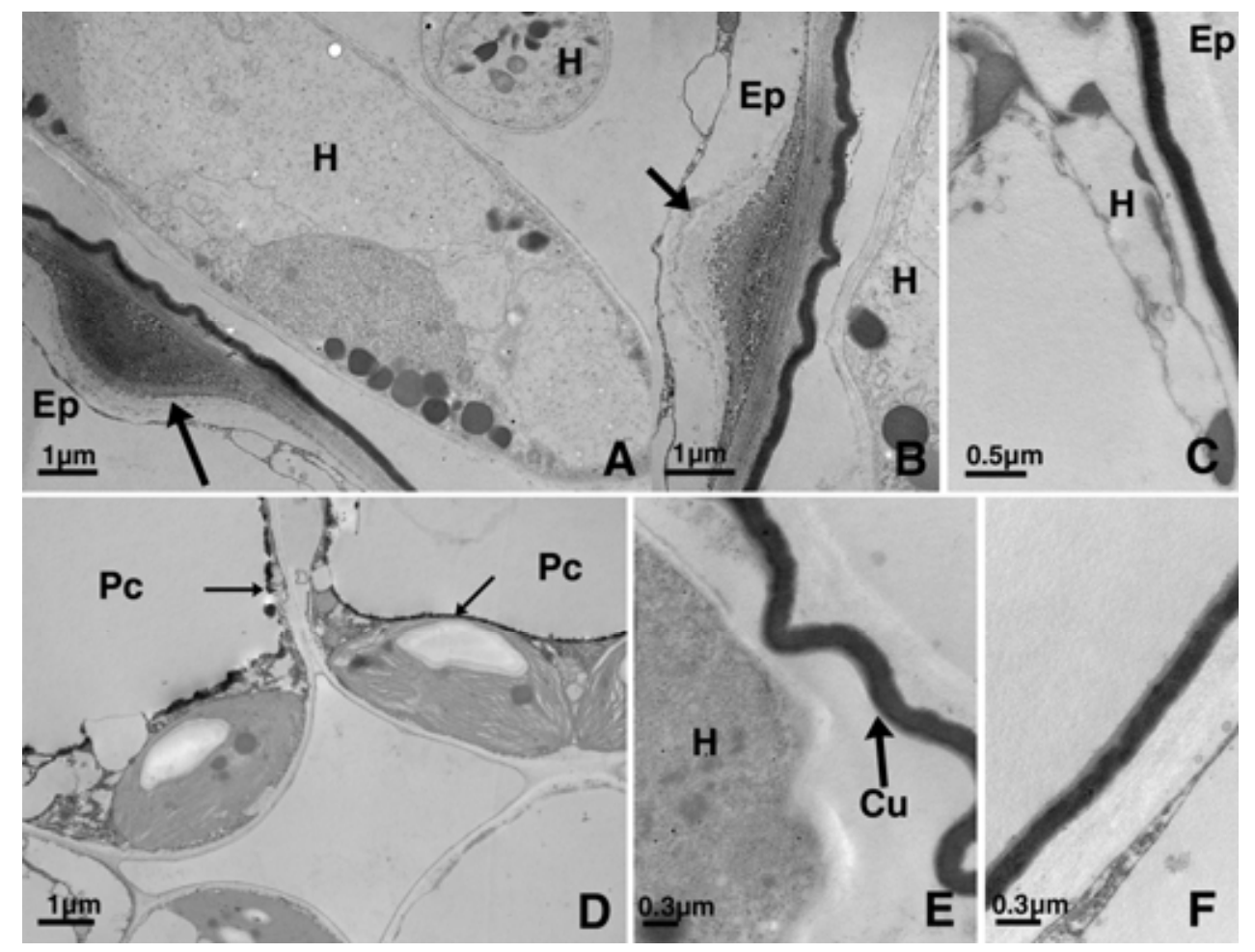

Fig. 5. Transmission electron micrographs of grapevine leaf tissues of plants preinoculated with Pythium oligandrum and $\mathbf{A}$ to $\mathbf{E}$, challenged or $\mathbf{F}$, unchallenged with Botrytis cinerea. A and B, Highly vacuolated hyphae $(\mathrm{H})$ of $B$. cinerea at the leaf surface and a wall apposition formed at a potential pathogen penetration site in the epidermis cells (Ep) (arrows). C, Severely damaged hyphae at the leaf surface. D, Accumulation of electron-dense material in parenchyma palisade cells (Pc) due to $B$. cinerea infection (arrows). E, Jagged cuticle $(\mathrm{Cu})$ fronting pathogen hypha $(\mathrm{H})$. Cuticle ultrastructure and thickness $(0.25 \pm 0.03 \mu \mathrm{m})$ are comparable to that of noninoculated leaves of plants pretreated with P. oligandrum $(0.23 \pm 0.03 \mu \mathrm{m}), \mathbf{F}$ but cuticle seems to be restored compared with that of the leaf challenged with $B$. cinerea without pretreatment $(0.16 \pm 0.02 \mu \mathrm{m})$ (Fig. 4D). 
Thus, oligandrin induces grapevine defense responses. When cryptogein, an elicitin from Phytophthora cryptogea, was assayed in the same experimental conditions, similar results were obtained. Grapevine plants were protected against $B$. cinerea infection and the molecular markers used as described above were expressed (data not shown). Grapevine response to elicitin is not associated with a hypersensitive reaction with either oligandrin or cryptogein. In the same way, in tobacco, oligandrin induced plant defense against pathogen infection and no necroses were observed $(32,41)$. In contrast, cryptogein is known to trigger a hyper- sensitive-like reaction (42). In addition, and with the exception of oligandrin, when elicitins are infiltrated in tobacco leaves, the cells of the corresponding area are killed and form a necrotic zone. Determination of plant reactivity to elicitins has been based mainly on this criterion (42). Tobacco and only some members of the family Brassicaceae were found to develop necroses in a cultivar-specific manner (42).

In conclusion, grapevine can be protected against $B$. cinerea leaf infection by a $P$. oligandrum inoculation or an elicitin pretreatment applied at the root level of rooted cuttings with compar-
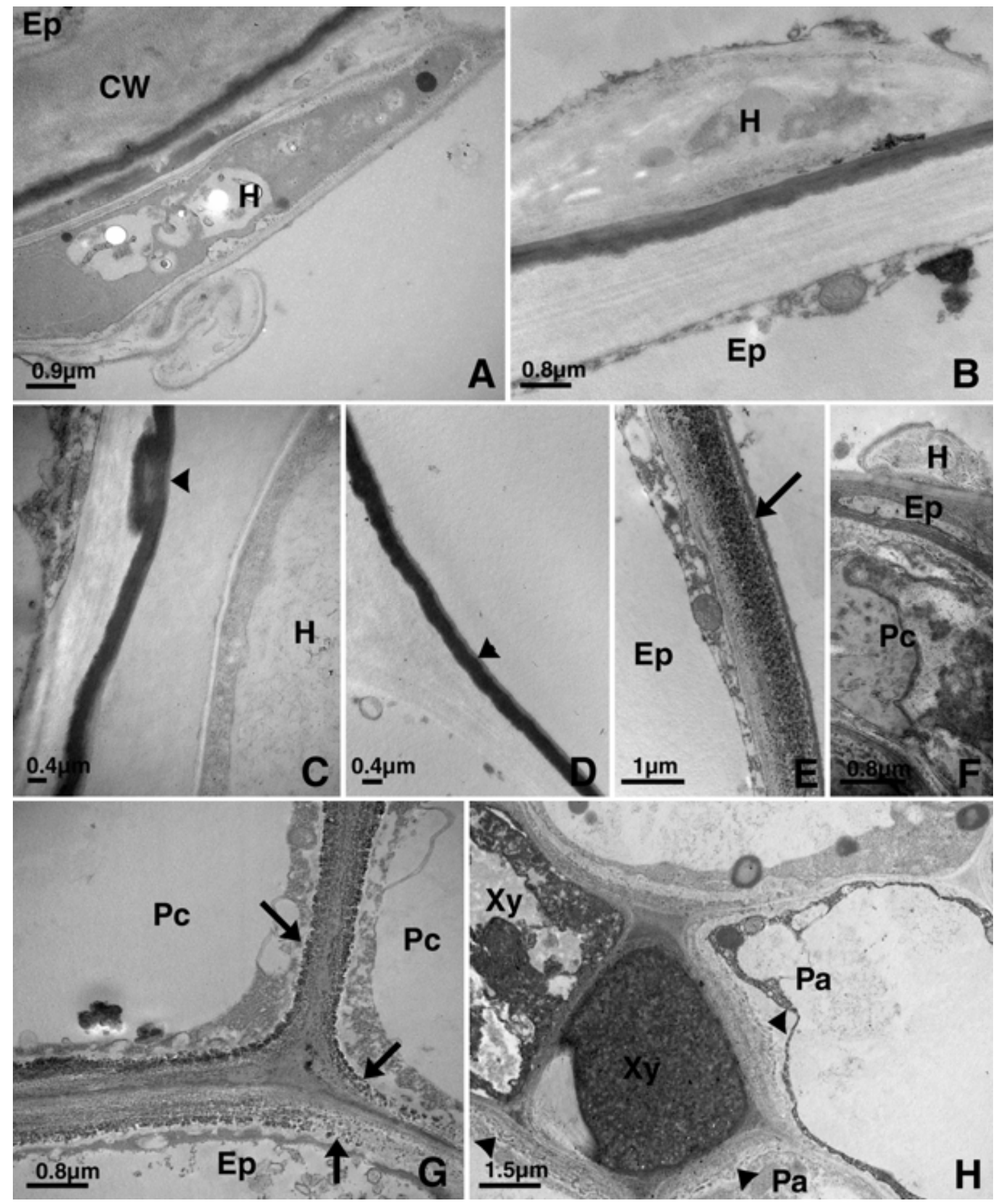

Fig. 6. Transmission electron micrographs of grapevine leaf tissues of plants pretreated with oligandrin and $\mathbf{A}$ to $\mathbf{C}$ and $\mathbf{E}$ to $\mathbf{H}$, challenged or $\mathbf{D}$, unchallenged with Botrytis cinerea. A and B, Dead hyphae $(\mathrm{H})$ detected at the leaf surface. C, Modification of cuticle morphology and thickness $(0.37 \pm 0.03 \mu \mathrm{m})$ compared with $\mathbf{D}$, oligandrin-treated plants unchallenged with the pathogen $(0.26 \pm 0.03 \mu \mathrm{m})$ and with the leaf challenged with $B$. cinerea without pretreatment $(0.16 \pm$ $0.02 \mu \mathrm{m})($ Fig. 4D). E, Impregnation of epidermis (Ep) cell wall with electron-dense material. F, Plant cell death occurring in the vicinity of pathogen hyphae (H). Ep, epidermis; Pc, parenchyma palisade cell. G, Reinforcement of lateral epidermal cell (Ep) and primary wall of palisade cells (Pc) with electron-dense material and deposit of callose (arrows). H, Occlusion of xylem vessels (Xy) with dense material and wall apposition in parenchyma vascular cells (Pa) (arrowheads). 
able efficiencies. The accumulation of defense-related gene transcripts differ. This could mean that in both cases oligandrin is involved but in the case of $P$. oligandrum preinoculation, other mechanisms may interfere with it. While results here indicate the induction of defense-related genes, an interesting complementation to the present work would be to study the kinetics of these inductions, to investigate enzymatic activity, immunodetection of gene products, and accumulation of phytoalexins. It also would be interesting to see if these two pretreatments could be efficient in reducing symptoms due to (i) Plasmopara viticola on leaves or
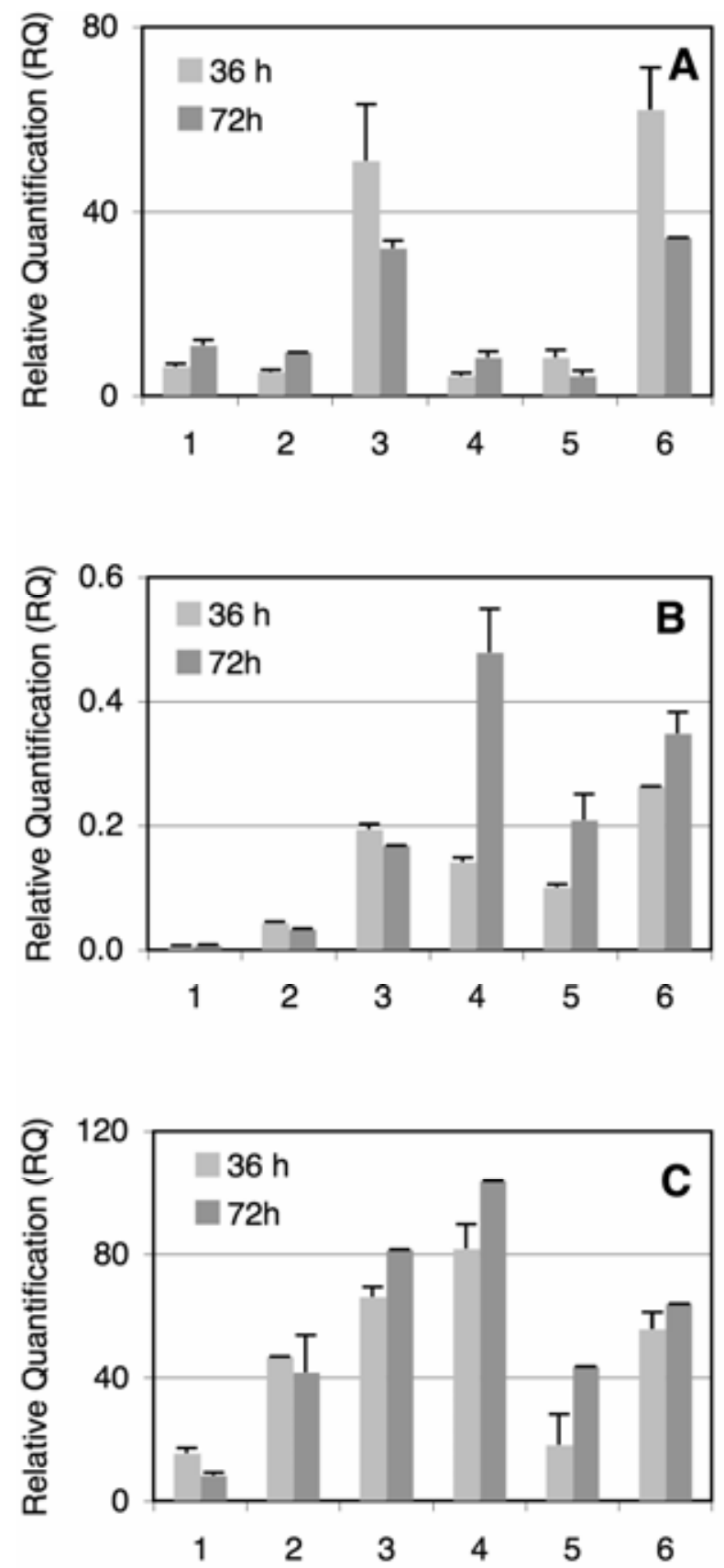

Fig. 7. Real-time quantitative reverse transcription (RT)-polymerase chain reaction analysis of the modification of some grapevine gene transcript accumulation. A, LTP-1, B, glucanase, and C, stilbene synthase. Equivalent cDNA samples were obtained from RT of RNA, from leaves of grapevine (cv. Pinot noir), following elicitation with Pythium oligandrum, oligandrin $(5 \mu \mathrm{g}$ per plant), and/or challenged or unchallenged with $B$. cinerea for $36 \mathrm{~h}$ (light gray bars) or for $72 \mathrm{~h}$ (dark gray bars). The transcript accumulation of three defense-related genes is expressed as the percentage of the amount of actin transcript. 1, control; 2, P. oligandrum; 3, oligandrin; 4, B. cinerea; 5, B. cinerea and $P$. oligandrum; and 6, B. cinerea and oligandrin. (ii) B. cinerea in grapevine inflorescences or at different stages of berry maturation, which are major problems in viticulture.

This work also brings evidence that the hypersensitive reaction is not an obligatory mechanism in the general elicitin mode of action. It may occur at a microscopic level, which is not as easy as the macroscopic one to detect. Therefore, it will be necessary to reassess plant reactivity to elicitin, not only with symptom description but also at the molecular level and to evaluate stimulation of plant defense. This work opens new perspectives in the field of plant defense mechanisms using elicitins as tools in phytoprotection.

\section{ACKNOWLEDGMENTS}

This research was supported by the INRA, The Conseil Régional de Bourgogne, and the Caisse Régionale du Crédit Agricole de ChampagneBourgogne. The Ph.D. work (N. Mohamed) was granted by the Ministry of Higher Education and Scientific Research of Libya. We thank I. Anselme-Bertrand (Centre de Microscopie Electronique Stéphanois, Faculté de Médecine, Saint-Etienne, France) and M.-A. Montesinos, (Société Elexience, Verrières le Buisson, France) for operating the variable pressure SEM (Centre de Microscopie Electronique Stéphanois), and C. Alabouvette and P. Bastable for critical and fruitful discussions.

\section{LITERATURE CITED}

1. Adrian, M., Jeandet, P., Veneau, J., Weston, L., and Bessis, R. 1997. Biological activity of resveratrol, a stilbenic compound from grapevines, against Botrytis cinerea, the causal agent for grey mold. J. Chem. Ecol. 23:1689-1702.

2. Aziz, A., Poinssot, B., Daire, X., Adrian, M., Bézier, A., Lambert, B., Joubert, J.-M., and Pugin, A. 2003. Laminarin elicits defense responses in grapevine and induces protection against Botrytis cinerea and Plasmopara viticola. Mol. Plant-Microbe Interact. 16:1118-1128.

3. Barka, E. A., Eullaffroy, P., Clément, C., and Vernet, G. 2004. Chitosan improves development, and protects Vitis vinifera L. against Botrytis cinerea. Plant Cell Rep. 22:608-614.

4. Benhamou, N., Bélanger, R. R., Rey, P., and Tirilly, Y. 2001. Oligandrin, the elicitin-like protein produced by the mycoparasite Pythium oligandrum, induces systemic resistance to Fusarium crown and root in tomato plants. Plant Physiol. Biochem. 39:681-696.

5. Benhamou, N., Rey, P., Chérif, M., Hockenhull, J., and Tirilly, Y. 1997. Treatment with the mycoparasite Pythium oligandrum triggers induction of defense-related reactions in tomato roots when challenged with Fusarium oxysporum f. sp. radicis lycopersici. Phytopathology 87:108122.

6. Ben-Shalom, N., Ardi, R., Pinto, R., Aki, C., and Fallik, E. 2003. Controlling gray mold caused by Botrytis cinerea in cucumber plants by means of chitosan. Crop Prot. 22:285-290.

7. Bezier, A., Lambert, B., and Baillieul, F. 2002. Study of defense-related gene expression in grapevine leaves and berries infected with Botrytis cinerea. Eur. J. Plant Pathol. 108:111-120.

8. Blein, J.-P., Coutos-Thevenot, P., Marion, D., and Ponchet, M. 2002. From elicitins to lipid transfer proteins: A new insight in cell signaling involved in plant defense mechanisms. Trends Plant Sci. 7:293-296.

9. Bonomelli, A., Mercier, L., Franchel, J., Baillieul, F., Beniziri, E., and Mauro, M.-C. 2004. Response of grapevine defenses to UV-C exposure. Am. J. Enol. Vitic. 55:52-60.

10. Busam, G., Kassemeyer, H.-H., and Matern, U. 1997. Differential expression of chitinases in Vitis vinifera L. responding to systemic acquired resistance activators or fungal challenge. Plant Physiol. 115:1029-1038.

11. Chang, S., Puryear, J., and Cairney, J. 1993. A simple and efficient method for isolating RNA from pine trees. Plant Mol. Biol. Rep. 11:113116.

12. Chet, I., and Inbar, J. 1994. Biological control of fungal pathogens. Appl. Biochem. Biotechnol. 48:37-43.

13. Clark, C. A., and Lorbeer, J. W. 1976. Comparative histopathology of Botrytis squamosa and B. cinerea on onion leaves. Phytopathology 66:1279-1289.

14. Cother, E. J., and Gilbert, R. L. 1993. Comparative pathogenicity of Pythium species associated with poor seedling establishment of rice in southern Australia. Plant Pathol. 42:51-157.

15. Elad, Y., and Evensen, K. 1995. Physiological aspects of resistance to Botrytis cinerea. Phytopathology 85:637-643.

16. Elad, Y., and Stewart, A. 2004. Microbial control of Botrytis spp. Pages 
223-241 in: Botrytis: Biology, Pathology and Control. Y. Elad, B. Williamson, P. Tudzynski, and N. Delen, eds. Kluwer Academic Publishers, Dordrecht, the Netherlands.

17. Fourie, J. F., and Holz, G. 1995. Initial infection processes by Botrytis cinerea on nectarine and plum fruit and the development of decay. Phytopathology 85:82-87.

18. Gomès, E., Sagot, E., Gaillard, C., Laquitaine, L., Poinssot, B., Sanejouand, Y.-H., Delrot, S., and Coutos-Thevenot, P. 2003. Nonspecific lipid-transfer protein genes expression in grape (Vitis sp.) cells in response to fungal elicitor treatments. Mol. Plant-Microbe Interact. 16:456-464.

19. Hammer, P. E., and Evensen, K. B. 1994. Differences between rose cultivars in susceptibility to infection by Botrytis cinerea. Phytopathology 84:1305-1312.

20. Hjeljord, L. G., Stensvand, A., and Tronsmo, A. 2000. Effect of temperature and nutrient stress on the capacity of commercial Trichoderma products to control Botrytis cinerea and Mucor piriformis in greenhouse strawberries. Biol. Control 19:149-160.

21. Hollenbach, B., Schreiber, L., Hartung, W., and Dietz, K. J. 1997. Cadmium leads to stimulated expression of the lipid transfer protein genes in barley: Implications for the involvement of lipid transfer proteins in wax assembly. Planta 203:9-19.

22. Holz, G., Gutschow, M., Coertze, S., and Calitz, F. J. 2003. Occurrence of Botrytis cinerea and subsequent disease expression at different positions on leaves and bunches of grape. Plant Dis. 87:351-358.

23. Hsieh, T.-F., Huang, J.-W., and Hsiang, T. 2001. Light and scanning electron microscopy studies on the infection of oriental lily leaves by Botrytis elliptica. Eur. J. Plant Pathol. 107:571-581.

24. Jung, H.-W., Kim, W., and Hwang, B.-K. 2003. Three pathogen-inducible genes encoding lipid transfer protein from pepper are differentially activated by pathogens, abiotic, and environmental stresses. Plant Cell Environ. 26:915-928.

25. Kapat, A., Zimand, G., and Elad, Y. 1998. Effect of two isolates of Trichoderma harzianum on the activity of hydrolytic enzymes produced by Botrytis cinerea. Physiol. Mol. Plant Pathol. 52:127-137.

26. Kim, K. H., Yoon, J. B., Park, H. G., Park, E. W., and Kim, Y. H. 2004. Structural modifications and programmed cell death of chili pepper fruit related to resistance responses to Colletotrichum gloeosporioides infection. Phytopathology 94:1295-1304.

27. Langcake, P., and Pryce, R. J. 1976. The production of resveratrol by Vitis vinifera and other members of the Vitaceae as a response to infection or injury. Physiol. Plant Pathol. 9:77-86.

28. Lascombe, M.-B., Milat, M.-L., Blein, J.-P., Panabières, F., Ponchet, M., and Prangé, T. 2000. Crystallization and preliminary X-ray studies of oligandrin, a sterol-carrier elicitor from Pythium oligandrum. Acta Crystallogr. D 56:1498-1500.

29. Le Floch, G., Benhamou, N., Mamaca, E., Salerno, M. I., Tirilly, Y., and Rey, P. 2005. Characterization of the early events in atypical tomato root colonization by a biocontrol agent, Pythium oligandrum. Plant Physiol. Biochem. 43:1-11.

30. Le Floch, G., Rey, P., Déniel, F., Benhamou, N., Picard, K., and Tirilly, Y. 2003. Enhancement of development and induction of resistance in tomato plants by the antagonist, Pythium oligandrum. Agronomie 23:455-460.

31. Leroux, P., Fritz, R., Debieu, D., Albertini, C., Lanen, C., Bach, J., Gredt, M., and Chapeland, F. 2002. Mechanisms of resistance to fungicides in field strains of Botrytis cinerea. Pest Manag. Sci. 58:876-888.

32. Lherminier, J., Benhamou, N., Larrue, J., Milat, M.-L., Boudon-Padieu, E., Nicole, M., and Blein, J.-P. 2003. Cytological characterization of elicitin-induced protection in tobacco plants infected by Phytophthora parasitica or phytoplasma. Phytopathology 93:1308-1319.

33. Livak, K. J., and Schmittgen, T. D. 2001. Analysis of relative gene expression data using real-time quantitative PCR and the $2\left(\mathrm{DDC}_{\mathrm{T}}\right)$ method. Methods 25:402-408.

34. Luft, J. H. 1961. Improvements in epoxy resin embedding methods. J. Biophys. Biochem. Cytol. 9:409.

35. Masih, E. I., and Paul, B. 2002. Secretion of $\beta-1,3$-glucanases by the yeast Pichia membranifaciens and its possible role in the biocontrol of
Botrytis cinerea causing grey mold disease of the grapevine. Curr. Microbiol. 44:391-395.

36. McQuilken, M. P., Whipps, J. M., and Cooke, R. C. 1992. Nutritional and environmental factors affecting biomass and oospore production of the biocontrol agent Pythium oligandrum. Enzyme Microbiol. Tech. 14:106111.

37. McQuilken, M. P., Whipps, J. M., and Cooke, R. C. 1992. Use of oospore formulations of Pythium oligandrum for biological control of Pythium damping-off in cress. J. Phytopathol. 135:125-134.

38. O'Neill, T. M., and Mansfield, J. W. 1982. Mechanisms of resistance to Botrytis in narcissus bulbs. Physiol. Mol. Plant Pathol. 20:243-256.

39. Paul, B., Chereyathmanjiyil, A., Masih, I., Chapuis, L., and Benoît, A. 1998. Biological control of Botrytis cinerea causing grey mold disease of grapevine and elicitation of stilbene phytoalexin (resveratrol) by a soil bacterium. FEMS Microbiol. Lett. 165:65-70.

40. Phillips, J. M., and Hayman, D. S. 1970. Improved procedures for clearing and staining parasite and vesicular-arbuscular mycorrhizal fungi for rapid assessment of infection. Trans. Br. Mycol. Soc. 55:158-161.

41. Picard, K., Ponchet, M., Blein, J.-P., Rey, P., Tirilly, Y., and Benhamou, N. 2000. Oligandrin, a proteinaceous molecule produced by the mycoparasite, Pythium oligandrum, induces resistance to Phytophthora parasitica infection in tomato plants. Plant Physiol. 124:379-395.

42. Ponchet, M., Panabières, F., Milat, M.-L., Mikes, V., Montillet, J.-L., Suty, L., Triantaphylides, C., Tirilly, Y., and Blein, J.-P. 1999. Are elicitins cryptograms in plant-oomycete communications? Cell. Mol. Life Sci. 56:1020-1047.

43. Rey, P., Benhamou, N., and Tirilly, Y. 1998. Ultrastructural and cytochemical investigation of asymptomatic infection by Pythium spp. Phytopathology 88:234-244.

44. Richter, H., Pezet, R., Viret, O., and Gindro, K. 2006. Characterization of 3 new partial stilbene synthase genes out of over 20 expressed in Vitis vinifera during the interaction with Plasmopara viticola. Physiol. Mol. Plant Pathol. 67:248-260.

45. Rijkenberg, F. H. J., de Leeuw, G. T. N., and Verhoeff, K. 1980. Light and electron microscopy studies on the infection of tomato fruits by Botrytis cinerea. Can. J. Bot. 58:1394-1404.

46. Robert, N., Ferran, J., Breda, C., Coutos-Thevenot, P., Boulay, M., Buffard, D., and Esnault, R. 2001. Molecular characterization of the incompatible interaction of Vitis vinifera leaves with Pseudomonas syringae pv. pisi: Expression of genes coding stilbene synthase and class 10 PR proteins. Eur. J. Plant Pathol. 107:249-261.

47. Robert, N., Roche, K., Lebeau, Y., Breda, C., Boulay, M., Esnault, R., and Buffard, D. 2002. Expression of grapevine chitinase genes in berries and leaves infected by fungal or bacterial pathogens. Plant Sci. 162:389400 .

48. Saligkarias, I. D., Gravanis, F. T., and Epton, H. A. S. 2002. Biological control of Botrytis cinerea on tomato plants by the use of epiphytic yeasts Candida guilliermondii strains 101 and US 7 and Candida oleophila I182: I. In vivo studies. Biol. Control 25:143-150.

49. Schröder, J., and Schröder, G. 1990. Stilbene and chalcone synthaserelated enzymes with key functions in plants specific pathways. Z. Naturforsch. 45c:1-8.

50. Sterk, P., Booij, H., Schellekens, G. B., Van Kammen, A., and De Vries, S. C. 1991. Cell-specific expression of the carrot EP2 lipid transfer protein gene. Plant Cell 3:907-921.

51. van Loon, L. C., and van Strien, E. A. 1999. The families of pathogenesisrelated proteins, their activities, and comparative analysis of PR-1 type proteins. Physiol. Mol. Plant Pathol. 55:85-97.

52. Wulff, E. G., Pham A. T. H., Cherif, M., Rey, P., Tirilly, Y., and Hockenhull, J. 1998. Inoculation of cucumber roots with zoospores of mycoparasitic and plant pathogenic Pythium species: Differential zoospores accumulation, colonization ability and plant growth response. Eur. J. Plant Pathol. 104:69-76.

53. Xiao, F., Goodwin, S. M., Xiao, Y., Sun, Z., Baker, D., Tang, X., Jenks, M. A., and Zhou, J.-M. 2004. Arabidopsis CYP86A2 represses Pseudomonas syringae type III genes and is required for cuticle development. EMBO J. 23:2903-2913. 